Reprod. Nutr. Dévelop., 1983, 23 (3), 525-535.

\title{
An investigation within a species (Gallus domesticus) of the hypothesis that embryonic and juvenile growth rates in birds are correlated
}

\author{
S. G. TULLETT, F. G. BURTON
}

Agricultural Research Council's Poultry Research Centre, Roslin, Midlothian EH25 9PS, Scotland

Summary. The hypothesis has been advanced from a study of several types of birds that the only way to alter growth rate in the juvenile is to alter the growth rate of the embryo. This was investigated within the species Gallus domesticus by comparing data from two pure lines (one with a slow and one a fast juvenile growth rate) and a broiler hybrid strain. Comparison of the data for the slow and fast line supported the general hypothesis. The incubation period was not significantly different in these two lines but the fast-line embryo was significantly heavier than the slow-line embryo throughout incubation. As a juvenile the fast-line chick grew almost twice as quickly as the slow-line chick to 8 weeks of age. There were problems in accomodating the broiler hybrid results because of a difference in developmental age when the embryos of this type of bird were compared with those of the other two lines. As an embryo the broiler hybrid appeared to grow faster than embryos of the fast-line type but this was not maintained after hatching for the fast-line birds quickly out-performed those from the broiler hybrid group.

The differences in embryo weight between the groups were always very small in comparison with the differences in chick weight as early as 7 days after hatching. It is unlikely therefore that embryo weight could be of practical use as an indirect selection criterion for growth rate in broilers.

\section{Introduction.}

It is extensively documented (Lack, 1968) that the length of the fledgling period in several types of wild birds is positively correlated with the length of the incubation period. Although Lack (1968) was apparently unsatisfied with his explanation he suggested that the easiest, or perhaps the only, way to evolve a change in the growth rate of the nestling was to evolve a parallel change in the growth rate of the embryo in the egg. Drent (1975) extended this argument by plotting data showing a negative correlation between the length of the incubation period and post-hatching growth rate.

If it could be proved that embryonic and juvenile growth rates in birds are correlated it could be of practical benefit, i.e. selection for juvenile growth in domestic birds could be based on some indicator of embryonic growth. It is first 
necessary, however, to test if the general hypothesis is applicable within a species. This communication describes an investigation of embryonic and juvenile growth rate in two pure lines of fowl lone having a slow juvenile growth rate and the other a fast juvenile growth rate) and a modern hybrid broiler strain and it outlines some of the difficulties involved in testing the hypothesis.

\section{Materials and methods.}

Fresh eggs from the three types of broiler fowl were supplied by D. B. Marshall (Newbridge) Ltd. In order to prevent any effects of egg storage on embryonic development (see Mather and Laughlin 1976, 1977) the eggs were incubated within two days of being layed.

Three experiments from a series of trials are described. Within each experiment, eggs from all three types of fowl were incubated in the same incubator and the parent flock age was equivalent. Flock age differed between experiments. Experiment 1 was an investigation of the juvenile growth characteristics of the three types of broiler chicken. Experiment 2 considered the growth of the embryo per se whilst Experiment 3 took into account such factors as initial egg composition. During the latter part of incubation the weight of the embryo is influenced by the initial weight of the egg (Jull and Heywang, 1930 ; Wiley, 1950) and eggshell porosity may also affect embryo weight either through effects on water loss (Tullett and Burton, 1982) or, in the case of low-porosity shells; by limiting respiratory gas exchange (Tullett and Deeming, 1982) and embryonic growth (Burton and Tullett, 1983). In most experiments, therefore, the mean egg weight and eggshell porosity (measured as the daily weight loss from the egg - see Tullett, 1981) were equalised across the egg types. Where this was not done, the embryo weight was corrected to a standard egg weight and to a shell porosity which would result in a $12 \%$ weight loss from the egg during incubation. Such a weight loss is regarded as optimal for good hatchability in domesticated species (see Tullett, 1981).

Experiment 1. - Fresh eggs from the three types of chicken were brought to the laboratory and incubated at $37.8^{\circ} \mathrm{C}$ and $55 \%$ relative humidity. The eggs were turned, hourly, through 90 degrees. Hatched chicks were allocated at random to rearing pens ( 10 birds per pen), the trial consisting of 3 pens per sex per type of bird (18 pens in all). The chicks were floor-brooded under continuous light and fed standard pelleted starter and finisher diets (Bolton and Blair, 1974). Individual bird weights and food intake per pen were recorded weekly up to 8 weeks of age when 2 birds per pen were prepared for carcase analysis.

Experiment 2. - The incubation procedure was identical to experiment 1. Forty-two hours after setting, 50 eggs for each type of bird were removed from the incubator and placed in cold water to arrest development. The number of pairs of somites were counted for the fertile eggs by injecting $1 \%(\mathrm{w} / \mathrm{v})$ methylene blue dye into the subgerminal cavity to provide a dark background to the embryo. No attempt was made to equalise fresh egg weight between the three groups because fertility of the eggs could not be ascertained before they 
were opened for examination, and further, there is no evidence of egg size affecting embryo development at this stage of incubation.

Using the egg weight loss records, eggs were removed after 10, 14, 18 and 19 days of incubation so that on each day the mean values for fresh egg weight and weight loss in the incubator was closely matched between egg types. Because all the eggs were in the same incubator, i.e. the same humidity, equalising the weight loss from the eggs between groups had the effect of equalising shell porosity. At the various stages of incubation the egg was opened, the embryo removed from the amniotic cavity and the yolk and the allantoic stalks cut as they entered the abdomen. The embryo was patted dry on absorbent tissue and weighed.

The remaining eggs were transferred to an incubator (Papworth) equipped to monitor the time of hatching of the chicks. In this incubator the hatch area was subdivided into 288 compartments, each large enough for one egg to hatch. A time-lapse cine camera was used to record the time of hatch by taking a picture of the hatch area every 10 minutes.

Experiment 3. - Fresh egg composition (weight of yolk and albumen) was measured on 25 eggs for each type of bird. After 18 days of incubation the weight of the embryo was obtained as described in experiment 2 and, in addition, the weight of the residual yolk sac and contents was recorded. At hatch chicks (whole chick) were weighed immediately they were free of the shell. They were then killed by decapitation, the yolk sac was removed from the abdominal cavity and the chick (true chick) reweighed.

\section{Results.}

Experiment 1. - The weekly mean body weights of the chicks from hatch to 8 weeks of age are given in table 1 and the corresponding analysis of variance in table 2. One week after hatch the heaviest male and female chicks were those from the fast-line followed by the broiler hybrid and slow line chicks respectively. This order was maintained at all stages up to 8 weeks of age. When tested at 1 and 8 weeks of age the difference in body weight between all the group means was significant $(P<0.001)$. Food consumption was highest in the fast line birds followed by the broiler hybrid and slow line respectively (tables 3 and 4), these differences being significant when tested at 8 weeks of age.

Although food conversion ratio was not statistically different in the three types of bird at 8 weeks of age (table 2) there was an indication that the faster growing birds (fast-line and broiler hybrid types) were more efficient.

Of the males, those in the fast line had significantly more body fat at 8 weeks of age whilst for females those in the broiler hybrid group had the highest fat content (tables 3 and 4). The slow-line birds of both sexes had the lowest body fat and highest protein content. There was significantly more body moisture in males than females although no effect of bird type was observed.

Experiment 2. - The mean initial weight for eggs removed from the incubator after $42 \mathrm{~h}$ and examined for somite development and for the eggs used 
TABLE 1

Mean body weights to eight weeks of age for three bird types

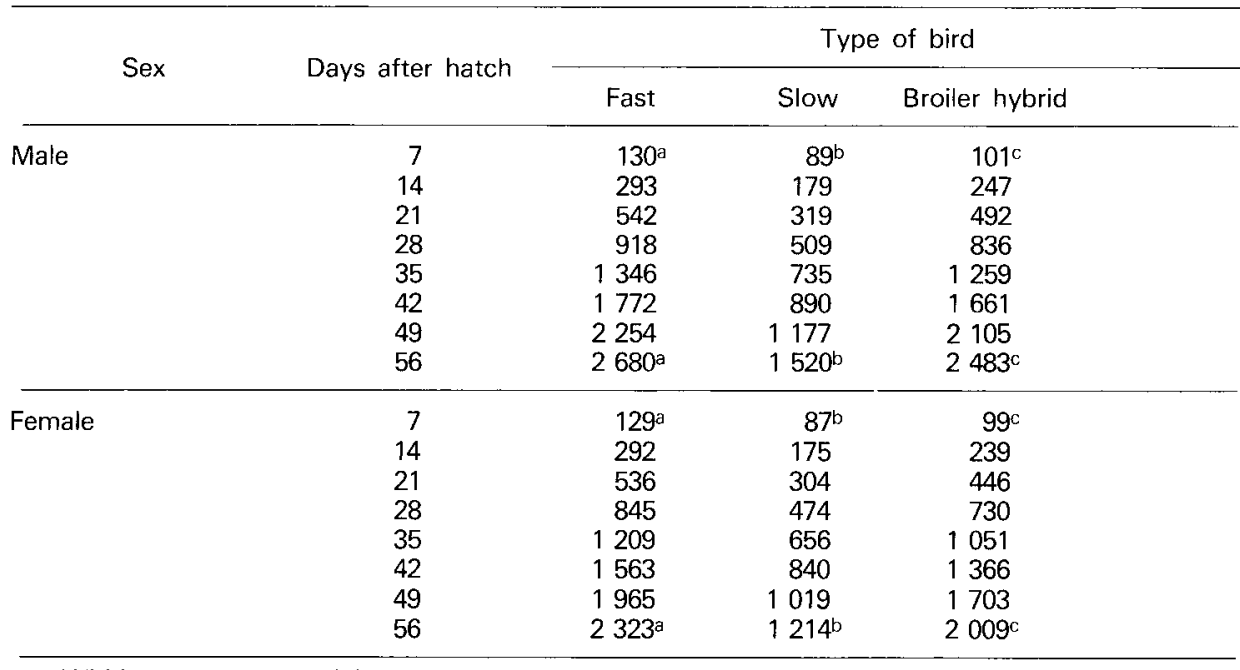

Within a row means followed by different letters are statistically different at the 0.001 level of probability.

TABLE 2

Analysis of variance for table 1

\begin{tabular}{llrrr}
\hline Variable & \multicolumn{1}{c}{ Source of variation } & df & M.S. & P \\
\hline Body weight 1 week & Sex & 1 & 0.89 & N.S. \\
& Bird type & 2 & 2556.06 & N.* $^{* *}$ \\
& Sex $\times$ Bird type interaction & 2 & 2.72 & N.S. \\
& Error & 10 & 37.59 & \\
\hline Body weight 8 weeks & Sex & 1 & 644869 & $* * *$ \\
& Bird type & 2 & 2125475 & ${ }^{* * *}$ \\
& Sex $\times$ Bird type interaction & 2 & 11140 & N.S. \\
& Error & 10 & 14514 & \\
\hline
\end{tabular}

${ }^{* * *} \mathrm{P}<0.001 ;$ N.S. not significant.

in the measurement of time of hatch was allowed to differ between groups since eggs of a chosen weight could not be guaranteed fertile for somite counting, or guaranteed to hatch. However, as early as $42 \mathrm{~h}$ of incubation the broiler hybrid embryos were clearly the most advanced (tables 5 and 6) and they retained this position as measured by embryo weight up to hatch when they 
TABLE 3

Food consumption, food conversion ratio and carcase analyses at 8 weeks for three bird types

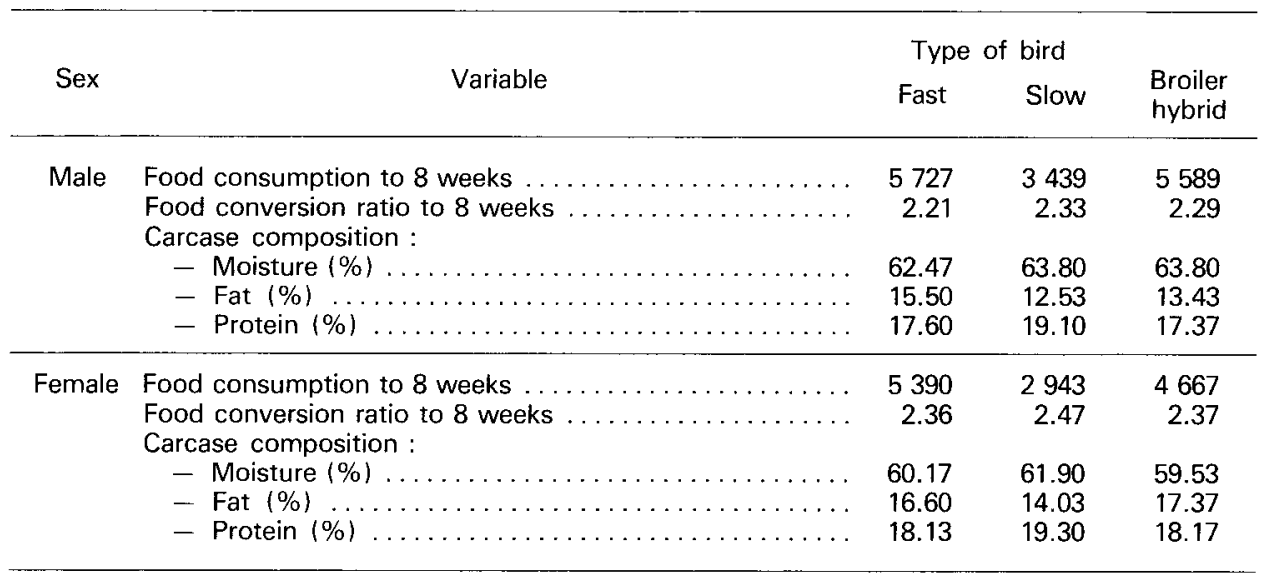

TABLE 4

Analysis of variance for table 3

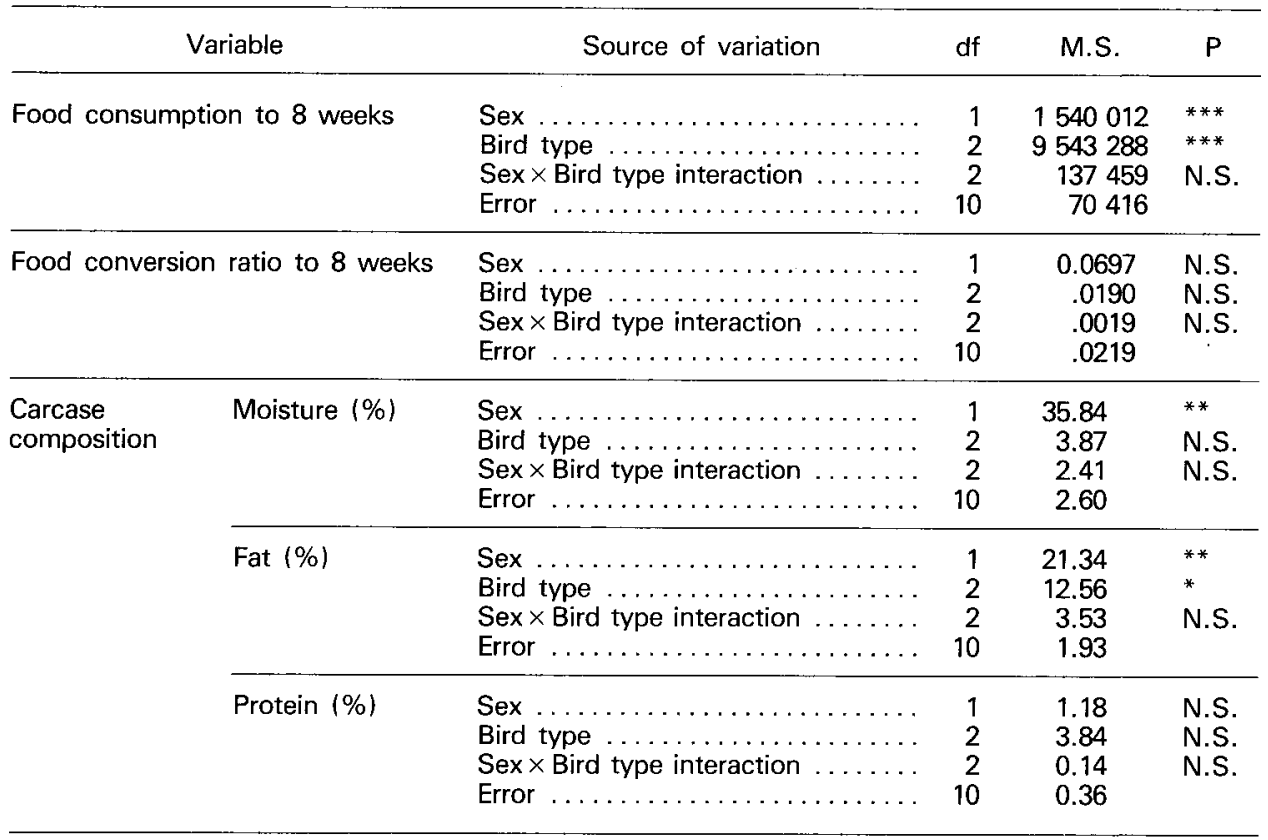

${ }^{*} \mathrm{P}<0.05 ;{ }^{*} \mathrm{P}<0.01 ;{ }^{* *} P<0.001 ;$ N.S. not significant. 
TABLE 5

Fresh egg weight, number of pairs of somites, wet embryo weight, weight loss from the eggs to the day of examination and incubation period for eggs for three bird types

\begin{tabular}{|c|c|c|c|c|c|c|}
\hline \multirow{2}{*}{$\begin{array}{c}\text { Stage } \\
\text { of incubation }\end{array}$} & \multirow{2}{*}{ Variable } & \multicolumn{3}{|c|}{ Type of bird } & \multirow[b]{2}{*}{$\begin{array}{l}\text { Broiler } \\
\text { hybrid }\end{array}$} & \multirow[b]{2}{*}{$\mathrm{n}$} \\
\hline & & & Fast & Slow & & \\
\hline $42 \mathrm{~h}$ & $\begin{array}{l}\text { Fresh egg weight } \\
\text { Somites }\end{array}$ & $\begin{array}{l}\langle\mathrm{g}\rangle \\
\text { (prs) }\end{array}$ & $\begin{array}{l}70.00^{\mathrm{a}} \\
13.51^{\mathrm{a}}\end{array}$ & $\begin{array}{l}65.61^{\mathrm{b}} \\
12.90^{\mathrm{a}}\end{array}$ & $\begin{array}{l}65.59^{b} \\
16.54^{b}\end{array}$ & $\begin{array}{l}37,40,43 \\
37,40,43\end{array}$ \\
\hline $10 d$ & $\begin{array}{l}\text { Fresh egg weight } \\
\text { Embryo weight } \\
\text { Egg weight loss }\end{array}$ & $\begin{array}{l}(\mathrm{g}) \\
(\mathrm{g}) \\
(\mathrm{g})\end{array}$ & $\begin{array}{l}66.67 \\
2.89^{\mathrm{ab}} \\
4.61\end{array}$ & $\begin{array}{l}66.66 \\
2.76^{a} \\
5.16\end{array}$ & $\begin{array}{l}66.37 \\
3.15^{b} \\
4.70\end{array}$ & $\begin{array}{l}15 \\
15 \\
15\end{array}$ \\
\hline $14 d$ & $\begin{array}{l}\text { Fresh egg weight } \\
\text { Embryo weight } \\
\text { Egg weight loss }\end{array}$ & $\begin{array}{l}(\mathrm{g}) \\
(\mathrm{g}) \\
(\mathrm{g})\end{array}$ & $\begin{array}{l}67.99 \\
13.04^{\mathrm{ab}} \\
6.27\end{array}$ & $\begin{array}{l}67.74 \\
12.15^{\mathrm{a}} \\
6.97\end{array}$ & $\begin{array}{l}66.09 \\
13.83^{b} \\
7.19\end{array}$ & $\begin{array}{l}15 \\
15 \\
15\end{array}$ \\
\hline $18 \mathrm{~d}$ & $\begin{array}{l}\text { Fresh egg weight } \\
\text { Embryo weight } \\
\text { Egg weight loss }\end{array}$ & $\begin{array}{l}(\mathrm{g}) \\
(\mathrm{g}) \\
(\mathrm{g})\end{array}$ & $\begin{array}{l}67.37 \\
28.62^{\mathrm{ab}} \\
8.19\end{array}$ & $\begin{array}{l}66.73 \\
27.53^{a} \\
8.25\end{array}$ & $\begin{array}{l}65.68 \\
30.22^{b} \\
8.34\end{array}$ & $\begin{array}{l}15 \\
15 \\
15\end{array}$ \\
\hline $19 d$ & $\begin{array}{l}\text { Fresh egg weight } \\
\text { Embryo weight } \\
\text { Egg weight loss }\end{array}$ & $\begin{array}{l}\text { (g) } \\
\text { (g) } \\
\text { (g) }\end{array}$ & $\begin{array}{l}65.38 \\
31.95 a \\
9.43\end{array}$ & $\begin{array}{c}65.29 \\
30.45^{a} \\
9.10\end{array}$ & $\begin{array}{l}66.46 \\
34.73^{b} \\
9.50\end{array}$ & $\begin{array}{l}15 \\
15 \\
15\end{array}$ \\
\hline Hatch & $\begin{array}{l}\text { Fresh egg weight } \\
\text { Incubation period }\end{array}$ & $\begin{array}{l}\text { (g) } \\
\text { (h) }\end{array}$ & $\begin{array}{r}67.73^{a} \\
490.25^{a}\end{array}$ & $\begin{array}{r}65.26^{\mathrm{b}} \\
491.05^{\mathrm{a}}\end{array}$ & $\begin{array}{r}65.46^{b} \\
484.86^{b}\end{array}$ & $\begin{array}{l}44,37,43 \\
44,37,43\end{array}$ \\
\hline
\end{tabular}

Within a row means without a following letter in common are statistically different at the 0.05 level of probability.

were the first to escape from the egg. In the slow-line only there was a significant positive regression $(P<0.05)$ between fresh egg weight and the number of somite pairs after incubation for $42 \mathrm{~h}$. The fast-line embryos were larger than slow-line embryos throughout incubation but the incubation periods of these two lines were not significantly different.

The difference in incubation periods between the three bird types reflected the difference in developmental age based on somite counts at $42 \mathrm{~h}$ of incubation (13.51 somite pairs $\equiv 42.2 \mathrm{~h} ; 12.90$ somite pairs $\equiv 41.3 \mathrm{~h}$; 16.54 pairs $\equiv 46.5 \mathrm{~h}$; based on Hamburger and Hamilton, 1951, but refined by observations made at the Poultry Research Centre by Mrs C. Mather, unpublished).

Experiment 3. - The amount of yolk in the fresh eggs examined in this experiment was significantly less in the broiler hybrid eggs than in the other two groups (tables 7 and 8). For eggs opened on day 18 of incubation the initial egg weight was not equalised between groups, instead multiple regression techniques were used to correct the measured embryo and yolk weights to a standard egg weight $(63 \mathrm{~g})$ and a shell porosity equivalent to a weight loss from the egg of $6.48 \mathrm{~g}$ 
TABLE 6

Analysis of variance for table 5

\begin{tabular}{|c|c|c|c|c|c|}
\hline $\begin{array}{c}\text { Stage } \\
\text { of incubation }\end{array}$ & Variable & & $d f$ & M.S. & $\mathbf{P}$ \\
\hline $42 \mathrm{~h}$ & $\begin{array}{l}\text { Fresh egg weight } \\
\text { Somites }\end{array}$ & $\begin{array}{l}\text { Bird type } \\
\text { Error } \\
\text { Bird type } \\
\text { Error }\end{array}$ & $\begin{array}{r}2 \\
117 \\
2 \\
117\end{array}$ & $\begin{array}{r}248.22 \\
24.41 \\
157.53 \\
7.65\end{array}$ & $\begin{array}{l}* * * \\
* * *\end{array}$ \\
\hline $10 \mathrm{~d}$ & $\begin{array}{l}\text { Fresh egg weight } \\
\text { Embryo weight } \\
\text { Egg weight loss }\end{array}$ & $\begin{array}{l}\text { Bird type } \\
\text { Error } \\
\text { Bird type } \\
\text { Error } \\
\text { Bird type } \\
\text { Error }\end{array}$ & $\begin{array}{r}2 \\
42 \\
2 \\
42 \\
2 \\
42\end{array}$ & $\begin{array}{r}.55 \\
13.58 \\
.57 \\
.14 \\
1.27 \\
1.12\end{array}$ & $\begin{array}{l}\text { N.S. } \\
* \\
\text { N.S. }\end{array}$ \\
\hline $14 \mathrm{~d}$ & $\begin{array}{l}\text { Fresh egg weight } \\
\text { Embryo weight } \\
\text { Egg weight loss }\end{array}$ & $\begin{array}{l}\text { Bird type } \\
\text { Error } \\
\text { Bird type } \\
\text { Error } \\
\text { Bird type } \\
\text { Error }\end{array}$ & $\begin{array}{r}2 \\
42 \\
2 \\
42 \\
2 \\
42\end{array}$ & $\begin{array}{r}15.84 \\
10.29 \\
10.60 \\
1.19 \\
3.45 \\
1.58\end{array}$ & $\begin{array}{l}\text { N.S. } \\
* * * \\
\text { N.S. }\end{array}$ \\
\hline $18 \mathrm{~d}$ & $\begin{array}{l}\text { Fresh egg weight } \\
\text { Embryo weight } \\
\text { Egg weight loss }\end{array}$ & $\begin{array}{l}\text { Bird type } \\
\text { Error } \\
\text { Bird type } \\
\text { Error } \\
\text { Bird type } \\
\text { Error }\end{array}$ & $\begin{array}{r}2 \\
42 \\
2 \\
42 \\
2 \\
42\end{array}$ & $\begin{array}{r}10.93 \\
18.69 \\
27.50 \\
4.85 \\
0.09 \\
0.97\end{array}$ & $\begin{array}{l}\text { N.S. } \\
\text { ** } \\
\text { N.S. }\end{array}$ \\
\hline $19 \mathrm{~d}$ & $\begin{array}{l}\text { Fresh egg weight } \\
\text { Embryo weight } \\
\text { Egg weight loss }\end{array}$ & $\begin{array}{l}\text { Bird type } \\
\text { Error } \\
\text { Bird type } \\
\text { Error } \\
\text { Bird type } \\
\text { Error }\end{array}$ & $\begin{array}{r}2 \\
42 \\
2 \\
42 \\
2 \\
42\end{array}$ & $\begin{array}{r}6.36 \\
12.15 \\
70.65 \\
4.33 \\
0.73 \\
2.74\end{array}$ & $\begin{array}{l}\text { N.S. } \\
* * * \\
\text { N.S. }\end{array}$ \\
\hline Hatch & $\begin{array}{l}\text { Fresh egg weight } \\
\text { Incubation period }\end{array}$ & $\begin{array}{l}\text { Bird type } \\
\text { Error } \\
\text { Bird type } \\
\text { Error }\end{array}$ & $\begin{array}{r}2 \\
121 \\
2 \\
121\end{array}$ & $\begin{array}{r}79.53 \\
20.87 \\
471.94 \\
61.68\end{array}$ & * \\
\hline
\end{tabular}

${ }^{*} \mathrm{P}<0.05 ;{ }^{* *} \mathrm{P}<0.01 ;{ }^{* *} \mathrm{P}<0.001 ;$ N.S. not significant.

to 18 days of incubation (tables 7 and 8 ). The embryos of the broiler hybrid type were heaviest followed by the fast and slow lines respectively the differences between all group means being significant. Conversely, at this stage, the amount of residual yolk was least in the broiler hybrid group with respectively more in the fast and slow lines.

At the moment of hatch there was no significant difference in the true chick weight between the broiler hybrid and fast line types but both were significantly heavier than the slow line type. Residual yolk weight was significantly less in the broiler hybrid than in the other two groups. 
TABLE 7

Mean fresh egg composition and embryo and yolk weights at 18 days of incubation and hatch for three bird types

\begin{tabular}{|c|c|c|c|c|c|c|}
\hline \multirow{2}{*}{$\begin{array}{c}\text { Stage } \\
\text { of incubation }\end{array}$} & \multirow{2}{*}{ Variable } & & \multicolumn{2}{|c|}{ Type of bird } & \multirow[b]{2}{*}{$\begin{array}{l}\text { Broiler } \\
\text { hybrid }\end{array}$} & \multirow[b]{2}{*}{$\mathrm{n}$} \\
\hline & & & Fast & Slow & & \\
\hline Fresh egg & $\begin{array}{l}\text { Fresh egg weight } \\
\text { Yolk weight } \\
\text { Albumen weight }\end{array}$ & $\begin{array}{l}(g) \\
(g) \\
(g)\end{array}$ & $\begin{array}{l}62.96 \\
18.17^{a} \\
37.28\end{array}$ & $\begin{array}{l}63.00 \\
18.55^{a} \\
36.81\end{array}$ & $\begin{array}{l}62.63 \\
17.47^{b} \\
37.69\end{array}$ & $\begin{array}{l}25 \\
25 \\
25\end{array}$ \\
\hline 18 days* & $\begin{array}{l}\text { Wet embryo weight } \\
\text { Yolk weight }\end{array}$ & $\begin{array}{l}(g) \\
(g)\end{array}$ & $\begin{array}{l}29.13^{a} \\
12.94^{a}\end{array}$ & $\begin{array}{l}26.50^{\mathrm{b}} \\
13.62^{\mathrm{b}}\end{array}$ & $\begin{array}{l}29.99^{c} \\
11.47^{c}\end{array}$ & $\begin{array}{l}42 \\
42\end{array}$ \\
\hline Hatch* & $\begin{array}{l}\text { True chick weight } \\
\text { Yolk weight }\end{array}$ & $\begin{array}{l}(g) \\
(g)\end{array}$ & $\begin{array}{r}39.47^{\mathrm{a}} \\
8.41^{\mathrm{a}}\end{array}$ & $\begin{array}{r}38.23^{\mathrm{b}} \\
8.33^{\mathrm{a}}\end{array}$ & $\begin{array}{r}39.75^{\mathrm{a}} \\
7.82^{\mathrm{b}}\end{array}$ & $\begin{array}{l}55,42,54 \\
55,42,54\end{array}$ \\
\hline
\end{tabular}

* Results given have been corrected by multiple regression to a standard $63 \mathrm{~g}$ egg and a $12 \%$ water loss from the egg throughout incubation.

Within a row means without a following letter in common are statistically different at the 0.05 level of probability.

TABLE 8

Analysis of variance for table 7

\begin{tabular}{|c|c|c|c|c|c|}
\hline $\begin{array}{ll}\text { Stage } \\
\text { of } & \text { incubation }\end{array}$ & Variable & Source of variation & $d f$ & M.S. & $P$ \\
\hline Fresh egg & $\begin{array}{l}\text { Fresh egg weight } \\
\text { Yolk weight } \\
\text { Albumen weight }\end{array}$ & $\begin{array}{l}\text { Bird type } \\
\text { Error } \\
\text { Bird type } \\
\text { Error } \\
\text { Bird type } \\
\text { Error }\end{array}$ & $\begin{array}{r}2 \\
72 \\
2 \\
72 \\
2 \\
72\end{array}$ & $\begin{array}{r}.98 \\
23.81 \\
7.42 \\
1.94 \\
4.88 \\
14.05\end{array}$ & $\begin{array}{l}\text { N.S. } \\
* \\
\text { N.S. }\end{array}$ \\
\hline 18 days & $\begin{array}{l}\text { Wet embryo weight } \\
\text { Yolk weight }\end{array}$ & $\begin{array}{l}\text { Bird type } \\
\text { Error } \\
\text { Bird type } \\
\text { Error }\end{array}$ & $\begin{array}{r}2 \\
121 \\
2 \\
121\end{array}$ & $\begin{array}{r}109.4 \\
3.27 \\
44.40 \\
2.49\end{array}$ & *** \\
\hline Hatch & $\begin{array}{l}\text { Wet embryo weight } \\
\text { Yolk weight }\end{array}$ & $\begin{array}{l}\text { Bird type } \\
\text { Error } \\
\text { Bird type } \\
\text { Error }\end{array}$ & $\begin{array}{r}2 \\
146 \\
2 \\
146\end{array}$ & $\begin{array}{l}10.1 \\
0.98 \\
3.95 \\
1.02\end{array}$ & ** \\
\hline
\end{tabular}

${ }^{*} \mathrm{P}<0.05 ;{ }^{* *} \mathrm{P}<0.01 ;{ }^{* *} \mathrm{P}<0.001 ;$ N.S. not significant.

\section{Discussion.}

Comparison of the data derived from a slow growing and fast growing line of broiler chick supported the general hypothesis outlined by Lack (1968), that the way to evolve a change in post-hatching growth rate was to change it 
throughout the whole of development including the embryo in the egg. After $42 \mathrm{~h}$ of incubation there was no significant difference in the biological ages (number of somites) of the embryos in these two types of chick (table 5). The incubation period was not significantly different in these two groups and it therefore seems reasonable to assume that the embryos were always compared at similar developmental ages. The fast-line embryo, however, was always heavier than the slow-line embryo throughout incubation, this difference being significant when tested at 18 days and at hatch on a large number of eggs (Experiment 3). After hatch the fast line birds grew almost twice as quickly as the slow-line types to 8 weeks of age.

There were problems in accommodating the broiler hybrid results which highlight some of the problems in investigations of this kind. For example, the avian embryo develops during the time the egg is travelling down the oviduct and the somite counts given in Table 5 indicate either that the broiler hybrid embryos were more advanced than the other two groups at oviposition or that early embryonic development is very much faster in this type of bird. The differences in the stage of development after $42 \mathrm{~h}$ of incubation appear, however, to be reflected directly in the incubation period. If the stage of development at oviposition is different then comparing the broiler hybrid and fast-line embryos, for example, at the same time after placing the eggs in the incubator is obviously not to compare them at the same developmental age. However, at a comparable stage, i.e. the very moment of escape from the egg, the true chick of the broiler hybrid was still heavier than the fast-line type but the difference was not significant. By 7 days after hatch the fast-line chick was heaviest by some $30 \mathrm{~g}$.

Egg weight is the major influence on the weight of the whole chick at hatch although its effects are modulated by the amount of water lost from the egg during incubation (Tullett and Burton, 1982). In the entire series of trials there was no evidence that the fast-line had any advantage due to a larger egg size. Indeed, in comparison with the broiler hybrid there was no indication in any of the results for the fast-line eggs or embryos of their superior post-hatching potential. For practical purposes, therefore, it appears that the embryo should be regarded as adapted to its environment within the egg and the adult to a different environment outside the egg and the growth of one cannot be predicted sufficiently accurately from the other. In addition, the differences in embryo weights between the groups were very small in comparison with the differences in chick weight found as early as 7 days after hatch indicating that embryo weight is unlikely to be of any use as an indirect selection criterion for the growth rate of the adult.

Experiments by other workers further highlight the difficulties in investigating the simple hypothesis because of the possible differences in egg weight, stage of embryo development at lay, rate of embryo development and incubation period. In chickens which had been selected bidirectionally for body weight at 8 weeks of age the incubation period was shorter in the low-weight line (Siegel et al., 1968). Although eggs in the high-weight line were larger than those in the low-weight line (Siegel, 1963), the embryos in the high-weight line were less advanced at 
oviposition (Coleman and Siegel, 1966) and at $42 \mathrm{~h}$ of incubation (Coleman, Siegel and Siegel, 1964) but were heavier after 14 days of incubation (Coleman, Siegel and Siegel, 1964).

Bidirectional selection for short or long incubation period has resulted in faster embryonic and adult growth in the short-incubation line (Vasquez and Bohren, 1977), a finding in agreement with the hypothesis advanced by Lack (1968) and in agreement with the data plotted for wild birds by Drent (1975). Within a population, however, there appears to be no phenotypic relationship between the length of the incubation period and the growth rate of the adult (Hays, 1941 ; Williams, Godfrey and Thompson, 1951) except, perhaps, where each chick is removed from the hatcher very shortly after hatch (Williams, Godfrey and Thompson, 1951), a situation which may be more comparable with that in the wild.

Reçu en juillet 1982.

Accepté en décembre 1982.

Acknowledgements. - It is a pleasure to acknowledge the help of Dr K. F. Laughlin and D. B. Marshall (Newbridge) Ltd in supplying the eggs necessary for this study, the technical assistance given by Mrs S. Smith and Mrs H. Hendry and the statistical advice by Mr D. Waddington.

Résumé. Corrélation entre la vitesse de croissance de l'embryon et du jeune chez Gallus domesticus.

II a été avancé que chez différentes espèces d'oiseaux, seule la modification de la vitesse de croissance de l'embryon permet d'agir sur la vitesse de croissance du jeune. Nous avons comparé deux lignées pures de Gallus domesticus, différent par la vitesse de croissance du jeune et une souche hybride. Bien que la durée d'incubation ne soit pas significativement différente, l'embryon de la lignée à croissance rapide est significativement plus lourd que celui de la lignée à croissance lente, à partir du $14^{\mathrm{e}}$ jour d'incubation. La croissance du jeune jusqu'à 8 semaines est deux fois plus rapide dans la première lignée que dans la seconde. Chez l'hybride la vitesse de croissance embryonnaire est supérieure à celle de la lignée à croissance rapide. La situation est inversée après l'éclosion.

Les différences entre les poids des embryons sont toujours très faibles par rapport à celles existant entre les poids des poulets dès le $7^{e}$ jour après l'éclosion. Il est donc peu probable que le poids de l'embryon puisse être de quelque utilité comme critère indirect de sélection chez les poulets de chair.

\section{References}

BOLTON W., BLAIR R., 1974. Poultry nutrition. Ministry of Agriculture, Fisheries and Food, $U . K$. , Bull. 174.

BURTON F. G., TULLETT, S. G., 1983. A comparison of the effects of eggshell porosity on the respiration and growth of domestic fowl, duck and turkey embryos. Comp. Biochem. Physiol. (in press).

COLEMAN J. W., SIEGEL P. B., 1966. Selection for body weight at eight weeks of age. 5. Embryonic state at oviposition and its relationship to hatchability. Poult. Sci., 45, 1008-1011.

COLEMAN J. W., SIEGEL H. S., SIEGEL P. B., 1964. Embryonic development of two lines of White Rocks. Poult. Sci., 43, 453-458. 
DRENT R. H., 1975. In FARNER D. S., KING J. R., Avian biology, (V), 333-420. Acad. Press, London.

HAMBURGER V., HAMILTON H. L., 1951. A series of normal stages in the development of the chick embryo. J. Morphol., 88, 49-92.

HAYS F. A., 1941. The importance of length of incubation period in Rhode Island Reds. Massachus. Agr. Exp. Stat., Bull. 384.

JULL M. A., HEYWANG B. W., 1930. Yolk assimilation during the embryonic development of the chick. Poult. Sci., 9, 393-404.

LACK D., 1968. Ecological adaptations for breeding in birds. Methuen Publ., London.

MATHER C. M., LAUGHLIN K. F., 1976. Storage of hatching eggs : the effect on total incubation period. Br. Poult. Sci., 17, 471-479.

MATHER C. M., LAUGHLIN K. F., 1977. Storage of hatching eggs : the effect on early embryonic development. Br. Poult. Sci., 18, 597-603.

SIEGEL. P. B., 1963. Selection for body weight at eight weeks of age. 2. Correlated responses of feathering, body weights and reproductive characteristics. Poult. Sci., 42, 896-905.

SIEGEL P. B., COLEMAN J. W., GRAVES H. B., PHILLIPS R. E., 1968. Incubation period of chickens selected bidirectionally for juvenile body weight. Poult. Sci, 47, 105-107.

TULLETT S. G., 1981. Theoretical and practical aspects of eggshell porosity. Turkeys, 29, 24-28.

TULLETT S. G., BURTON F. G., 1982. Factors affecting the weight and water status of the chick at hatch. Br. Poult. Sci., 23, 361-369.

TULLETT S. G., DEEMING D. C., 1982. The relationship between eggshell porosity and oxygen consumption of the embryo in the domestic fowl. Comp. Biochem. Physiol., 72A, 529-533.

VASQUEZ C. G., BOHREN B. B., 1977. Correlated responses in some economic traits from selection for fast and slow hatching. Poult. Sci., 57, 330-335.

WILEY W. H., 1950. The influence of egg weight on the pre-hatching and post-hatching growth rate in the fowl. I. Egg weight - embryonic development ratios. Poult. Sci., 29, 570-574.

WILLIAMS C., GODFREY G. F., THOMPSON R. B., 1951. The effect of rapidity of hatching on growth, egg production, mortality and sex ratios in the domestic fowl. Poult. Sci., 30. 599 606. 